\title{
MEMBERDAYAKAN KECERDASAN KINESTETIK ANAK UNTUK BUDAYA LITERASI BAHASA
}

\author{
Imam Suhaimi \\ email: suhaimi_yes@yahoo.co.id \\ Universitas Kahuripan Kediri
}

\begin{abstract}
The basic principle that children play, activity appears frequently encountered is the movement of an active and attractive. This is a kinesthetic intelligence of children who should be able to be utilized as the adults who are around them, this kinesthetic intelligence when combined with the intelligence of language acquisition, it will create a habituation since early child literacy. The language is a human identity itself requires us to continue to develop the science of language, therefore this paper tries to accommodate the desire that through discussions and cultural integration of kinesthetic intelligence language literacy. Cultural literacy is expected to grow since early on the initiative of the children themselves without pressure from teachers, parents, or those surrounding the other, both of language acquisition, Indonesian, or a foreign language.
\end{abstract}

Keywords: kinesthetic intelligence, literacy, language.

\begin{abstract}
Abstrak
Prinsip dasar anak yaitu bermain, aktifitas yang muncul yang sering dijumpai adalah gerakan yang aktif dan atraktif. Inilah sebuah kecerdasan kinestetik anak yang seharusnya mampu kita manfaatkan sebagai orang dewasa yang ada di sekitar mereka, kecerdasan kinestetik ini apabila dikombinasikan dengan kecerdasan pemerolehan bahasa maka akan tercipta sebuah pembiasaan literasi anak semenjak dini. Bahasa yang merupakan identitas sebagai manusia itu sendiri menuntut kita untuk terus mengembangkan ilmu bahasa, maka dari itu tulisan ini mencoba mengakomodir keinginan tersebut melalui pembahasan keterpaduan kecerdasan kinestetik dan budaya literasi bahasa. Budaya literasi diharapkan tumbuh semenjak dini atas prakarsa anak itu sendiri tanpa ada tekanan dari guru, orang tua, atau orang sekitarnya yang lain, baik dalam pemerolehan bahasa Indonesia, atau Bahasa asing.
\end{abstract}

Kata kunci: kecerdasan kinestetik, literasi, bahasa.

\section{PENDAHULUAN}

Pembiasaan suatu hal memang seharusnya dilakukan sejak dini, termasuk membudayakan literasi. Menurut beberapa penelitin menunjukkan bahwa masa emas seseorang berada pada kisaran umur 0-8 tahun, dimana sel jaringan otak anak mengalami pertumbuhan yang sangat signifikan. Maka perlu pemaafaatan usia tersebut yang terjadi hanya sekali seumur hidup dengan sangat baik.

Sehingga sangatlah penting dalam merangsang pertumbuhan kecerdasan otak anak dengan memberikan perhatian labih pada pemberian gizi, menjaga kesehatan dan pelayanan pendidikan, serta pemerolehan bahasa.

Salah satu perhatian yang perlu mendapat jatah lebih yaitu tentang pendidikan anak, salah satunya budaya literasi sejak dini, dimana ketika kelak dewasa mereka bisa menjadi manusia unggul.

Ada beberapa alasan mengapa perlunya pembudayaan literasi ini sejak dini, diantaranya semakin pesatnya dunia teknologi pada zaman saat ini. Mempersiapkan anak agar tidak menjadi konsumen yang tidak terarah adalah tantangan bagi orang tua, kecanggihan 
teknologi yang dibarengi dengan kecerdasan dan kemampuan literasi akan menunjang kualitas diri seseorang dan berpengaruh secara nyata terhadap kualitas sumber daya manusia bangsa secara umum.

Memanfaatkan kecerdasan kinestetik anak terhadap kemampuan literasi yang baik, akan mampu membendung pengalihan pengaruh konten-konten negatif teknologi seperti game-game on-line bergenre kekerasan atau situs-situs radikal menuju penciptaan karya-karya nyata. Ini mampu dilaksanakan jika seseorang memiliki literasi bahasa yang baik karena tidak akan terpengaruh dengan sebuah opini dari satu sudut pandang saja.

Empat komponen penting dalam literasi yaitu: representasi, bahasa, produksi dan Khalayak (Buckingham, 2007: 47). Salah satu komponen literasi menurut Buckingham adalah bahasa yaitu individu tidak saja dituntut mampu berbahasa namun juga memahami aneka kode dan konvensi pada berbagai genre konten. Hal ini membutuhkan kemampuan untuk memahami berbagai retorika fungsi bahasa seperti persuasi, eufimisme, hiperbola dan sebagainya. Sebab itulah penulis tertarik untuk mengupas literasi bahasa ditinjau dari segi pemaduan kecerdasan kinestetik. Literasi bahasa yang dimaksud di sini adalah bagaimana seseorang memiliki pandangan dan kebiasaan yang istiqomah dalam memperoleh bahasa yang diaktualkan dalam sebuah ide, kritis, dan taktis dalam berbahasa.

Pemerolehan bahasa oleh manusia merupakan anugerah tuhan yang begitu besar, ini yang membedakan antara manusia dan hewan. Pemerolehan bahasa pada anak bergantung pada lingkungannya, bagus atau buruknya merupakan hasil dari pengalaman yang mereka dapat. Lebih jauh tulisan ini ingin mengurai kemampuan anak tidak hanya sebatas memperoleh bahasa, namun juga giat dalam literasi. Meski demikian akan ada kemungkinan keterbatasan gramatikal yang akan diperoleh anak dalam pemerolehan bahasa dalam pemanfaatan kecerdasan kinestetik, oleh karenanya pada pembahasan tidak ditekankan sebuah linguistic competence sebagaimana teori ahli linguistik terkemuka Noam Chomsky yang menekankan pada kompetensi gramatikal bahasa sesuai gramatikal sempurna.

Tulisan ini berusaha mengulas perspektif literasi bahasa dari pemanfaatan kecerdasan kinestetik anak dalam penyediaan bibit generasi unggul di masa yang akan datang dengan mengutamakan kompetensi komunikatif sebagaimana pandangan ahli linguistik Dell Hymes .

\section{HASIL DAN PEMBAHASAN}

\section{A. Kecerdasan Kinestetik, Literasi, dan Kompetensi Berbahasa}

Kecerdasan kinestetik sering dimanfaatkan untuk meraih kemampuan yang bersifat psikomotorik, sedangkan pemerolehan bahasa lebih condong pada pendekatan kognitif.

Akan menjadi pertanyaan apabila pemerolehan bahasa 
menggunakan pendekatan kecerdasan kinestetik, bagaimana caranya? Apakah hasilnya mampu mengangkat perkembangan bahasa anak? Mampukah menumbuhkan minat literasi? Dan lain sebagainya.

Ruhaena (2015) menjelaskan bahwa proses belajar dimediasi oleh bahasa, oleh karena itu kemampuan literasi selalu diawali oleh perkembangan bahasa. Orang dewasa memberikan pertanyaan, ungkapan/pernyataan, dan memberi dukungan sehingga terjadi proses belajar dan kemampuan anak kemudian meningkat. Oleh karenya akan terjadi proses sosial antara individu. Tataran tersebut terjadi sebuah interaksi dan kominikasi dan membutuhkan komunikasi dan polah gerak untuk mengungkapkannya.

\section{Kecerdasan Kinestetik}

Kecerdasan kinestetik adalah merupakan kemampuan seseorang dalam mengontrol gerakannya atau mengolah gerakan tubuhnya dengan baik. Anak memiliki kecerdasan kinestetik yang tinggi, biasanya dengan cepat menguasai aktivitasaktivitas yang melibatkan fisik, baik itu motorik kasar maupun motorik halus. Selain itu, mereka juga sering kali mengekspresikan gagasan atau emosinya melalui gerak tubuh. Peristiwa ini dapat kita jumpai di lembaga pendidikan anak usia dini maupun sekolah dasar.

Kecerdasan gerak-kinestetik berkaitan dengan kemampuan menggunakan gerak seluruh tubuh untuk mengekspresikan ide dan perasaannya serta keterampilan menggunakan tangan untuk mencipta atau mengubah sesuatu (Musfiroh, 2008: 50). Kecerdasan ini termasuk kecerdasan merangsang akan peristiwa-peristiwa baru untuk ditanggapi.

Secara umum anak usia dini pada tingkat sekolah dasar memiliki keingintahuan yang tinggi, tidak jarang dari mereka yang mengaplikasikan dengan gerak tubuh. Misal ketika pertama kali menjumpai kereta api, sepontanitas mereka akan bertanya "itu kereta? Panjang sekali”. Seraya mengatakan benda yang ditunjuk dan terkadang mereka juga memperaktekkan sebuah gerakan tangan yang seolaholah ada benda panjang yang sedang dipegang. Bahkan para orang tua pun memberikan contoh gerakan ekspresi yang mewakili sebuah benda yang diperbincangkan dengan si anak.

Kemampuan kinestetik sejatinya tidak dimiliki semua anak, namun mayoritas anak usia dini mempunyai kemampuan kinestetik yang baik. Dimana jika hal ini disadari oleh orang tua atau pendidik dalam hal ini guru di sekolah, maka sebuah potensi besar sebenarnya ada di hadapan mereka. Guru atau orang tua dapat memanfaatkan pola gerak anak dalam mendidik dan mengarahkan bakat anak, bukan menjadikan sebuah kelemahan atau dianggap sebuah kenakalan dan kebandelan.

Dalam hal pemberdayaan kemampuan kinestetik anak, guru atau orang tua bisa menciptakan suasana persahabatan dengan anak. Artinya, setiap gerakan yang dilakukan anak dianggap sebuah ekplorasi yang butuh perhatian, baik itu gerakan yang dianggap positif atau negatif. 


\section{Kinestetik yang atraktif, variatif, dan inovatif}

Anak usia pendidikan dini sampai usia pendidikan dasar memiliki aktifitas yang sangat atraktif, ketika yang demikian diolah akan menjadi sebuah modal pengembangan produktifitas kinestetik anak. Kemampuan kinestetik anak yang bervariatif dapat dimanfaatkan sebagai media pembelajaran anak pada hal-hal baru, seperti anak yang suka menonjok atau memukul orang lain bisa diarahkan pada keterampilan seni bela diri, bermain alat musik yang dipukul semacam gendang, dan halhal positif lainnya.

Berbagai variasi gerak anak sebetulnya menuntut kejelian orang tua dan guru bagaimana mampu mengaplikasikan keinginan dan bakat anak, tidak sedikit anak yang secara sengaja atau tidak sengaja memancing "lawannya" agar ikut dalam tingkah laku yang diciptakan. Satu contoh ketika anak melakukan gerakan lari, di situ ada beberapa kemungkinan tujuan si anak, salah satunya "lari" adalah berbeda dengan "jalan" serta berbeda pula dengan "berbaris". Di sinilah peluang orang tua dan guru untuk memberikan pembelajaran baru dengan memberikan makna atau menjelaskan nama dari perbedaan "lari, jalan, dan berbaris".

Tantangan guru dan orang tua tidak berhenti di situ saja, perlu sebuah inovasi gerakan yang ditunjukkan anak dengan mengkreasikan untuk ditampilkan gerakan yang lain hasil dari pengembangan gerakan anak. Ambillah satu contoh ketika anak mengatakan "kereta" dengan ekspresi tangan menunjukkan benda yang panjang, maka guru atau orang tua bisa melempar kosa kata benda yang sejenis yang lain seperti "bus tinggi" dengan menunjukkan tangan ditarik keatas atau "mobil sedan kecil" dengan mempertemukan kedua telapak tangan yang hampir merapat. Pengembangan polah gerak demikian haruslah mampu mengundang anak untuk menirukan atau bahkan berinovasi mencari gerakan yang lain dengan kosa kata yang sama ataupun dengan kosa kata yang lain dengan gerakan yang lain pula.

Ketika orang tua atau guru mampu memanfaatkan dan mengembangkan potensi kinestetik anak, maka memberi peluang meningkatkan kecerdasan pola berfikir anak. Anak akan selalu terangsang untuk menciptakan sebuah gerakan baru atas kosa kata, kejadian, atau benda yang baru dijumpai. Juga demikian sebaliknya anak akan termotivasi untuk mencari nama akan hal yang baru dijumapainya.

$\begin{array}{rrr}\text { Secara } & \text { tidak } & \begin{array}{r}\text { disadari } \\ \text { demikian }\end{array} \\ \text { sesungguhnya } & \begin{array}{l}\text { yang } \\ \text { merupakan }\end{array} & \text { sebuah } \\ \text { permainan, }\end{array}$
mengajak anak untuk tebak-tebakan, menantang anak melakukan sesuatu. Dengan permainan anak akan menjadi senang dan mudah diajak belajar. Supriyadi (2002; 4) menjelaskan bahwa Bruner dan Danalson dari telaahnya menemukan bahwa sebagian pembelajaran terpenting dalam kehidupan diperoleh dari masa kanak-kanak yang paling awal, dan pembelajaran itu sebagian besar diperoleh dari bermain. 


\section{Pembelajaran Literasi}

Berbicara

tentang

pembelajaran literasi, Axford (dalam

Subandiyah.2015) mengatakan

bahwa salah satu tujuan pembelajaran literasi adalah membantu siswa memahami dan menemukan strategi yang efektif dalam hal kemampuan membaca dan menulis, termasuk di dalamnya kemampuan menginterpretasi makna teks yang kompleks dalam struktur tata bahasa dan sintaksis (dalam www.prioroitaspendidikan.org).

Istilah literasi setidaknya mengandung makna memperoleh informasi secara kritis dan mentafsirkannya dalam kehidupan nyata. .

Orang yang memiliki kemampuan literasi yang baik akan mampu mengakses dan menggunakan informasi secara efisien dan efektif, mengevaluasi informasi secara kritis dan sesuai kompetensinya, serta mampu menggunakan secara akurat dan kreatif Lebih spesifik, literasi adalah keberaksaraan, yaitu kemampuan menulis dan membaca, budaya literasi dimaksudkan untuk melakukan kebiasaan berfikir yang diikuti oleh sebuah proses membaca, menulis dan mempresentasikan yang pada akhirnya apa yang dilakukan dalam sebuah proses kegiatan tersebut akan menciptakan karya.

Membudayakan atau membiasakan membaca dan menulis itu perlu proses apabila dalam suatu kelompok masyarakat kebiasaan tersebut memang belum ada atau belum terbentuk (Haryanti, 2014). Literasi juga erat kaitannya dengan kebiasaan.

76 | Jurnal Kredo Vol. 1 No. 1 Oktober 2017
Sebuah persoalan terkadang muncul bukan karena tidak bisa, hanya tidak biasa. Seperti budaya membaca, anak-anak sampai dewasa masyarakat kita sebenarnya sudah banyak yang sudah tidak buta aksara, namun masih sedikit yang mempunyai minat membaca terutama membaca hal informatif. Pemerintah dalam hal ini Kementerian Pendidikan dan Kebudayaan mulai tahun 2015 sebenarnya sudah mulai mencanangkan Gerakan Literasi Sekolah (GLS ) guna memperkuat gerakan penumbuhan budi pekerti sebagaimana dituangkan dalam Peraturan Menteri Pendidikan dan Kebudayaan Nomor 23 Tahun 2015. Salah satu kegiatannya adalah kegiatan 15 menit membaca buku nonpelajaran sebelum waktu belajar dimulai.

Membiasakan sejak dini
budaya membaca utamanya
membaca buku sangat penting,
beberapa kendala dan alasan
biasanya diungkapkan oleh guru atau
orang tua kenapa anak tidak suka
membaca. Salah satunya karena si
anak malas. Mari kita tengok lagi
kebiasaan anak dan beban yang
mereka dapat saat menempuh
pendidikan dasar.

Anak hanya mau membaca ketika disuruh gurunya, itupun lebih banyak membaca soal-soal, bukan teks informatif pengetahuan. Artinya, anak akan membaca ketika ada soal atau tugas dari guru. Dengan kata lain membaca adalah tugas dan beban bukan kebutuhan. Budaya literasi atau melek bacaan sebenarnya bisa dimulai sejak dini, salah satu cara yang bisa dipakai adalah dengan memanfaatkan kemampuan kinestetik anak. 
Anak yang sangat atraktif dan suka bergerak sebetulnya sudah menunjukkan kemampuan membaca sesuatu, perlu pemanfaatan dari kemampuan kinestetik anak ini agar anak mengaplikasikan dalam baca yang sebenarnya. Untuk itu, perlu merangsang anak agar memanfaatkan kemampuan kinestetiknya tersalurkan dengan baik. Misal, taruhlah seorang guru memberikan sebuah kosa kata di papan tulis "tentara". Berilah tugas kepada anak supaya mencari gerakan yang menyerupai tentara. Atau sebaliknya, guru memberikan gerakan-gerakan seperti tentara seraya sebelumnya menuliskan beberapa kata di papan tulis kemudian anak didiknya menebak kata mana yang sesuai dengan gerakan guru. Kegiatan demikian juga bisa dilakukan dalam sebuah kelompok, biarkan mereka menuliskan sendiri kosa kata dan meminta teman yang lain menjadi model.

Pemanfatan kemampuan kinestetik yang seperti diuraikan di atas dapat dikembangkan dalam permainan kalimat, bukan sekedar kata per kata. Suatu contoh guru menuliskan

"seekor kelinci melompat mencari wortel, setelah itu memakannya"

Di sini guru bisa menjadi model terlebih dahulu, sambil membaca kalimat tersebut juga mempraktikkan bagaimana seekor kelinci melompat mencari wortel dan memakannya. Setelah itu guru bisa memberikan kalimat yang lain dan meminta siswa untuk membaca kalimat dengan melakukan ekspresi dan gerakan yang sesuai dengan kalimat yang dibaca.

Selain untuk mengajak anak bermain, metode seperti ini mampu mengajak siswa berimajinasi ketika membaca sesuatu. Ketika imajinasi anak mampu menguasi saat membaca, maka keinginan untuk terus membaca akan tumbuh. Lebih jauh, metode ini akan dibahas lebih mendalam pada uraian di bawah tentang kepaduan kecerdasan kinestetik dan budaya literasi bahasa.

\section{Pemerolehan Bahasa}

Kemampuan bahasa setiap individu jelas berbeda, bergantung bagaimana lingkungan disekitarnya memberikan porsi terhadap pemerolehan bahasa itu sendiri. Pemerolehan kemampuan bahasa seseorang (anak/dewasa) sejatinya erat hubungannya sebagai jati diri manusia, artinya manusia adalah makhluk yang memiliki kompetensi bahasa yang merupakan identitas manusia itu. Sebagaimana kutipan berikut:

.. Manusia bangga akan
kebijaksanaan yang
dianggapnya sebagai bakat,
manusia bangga penemuan-
penemuan tekniknya, tetapi
manusia jarang
mengembangkannya, malah
sering minatnya hanya berupa
banyak keluhan atas
kekurangan-kekurangan
bahasanya dan cacian
terhadap verbalisme. Namun
sebenarnya bahasa adalah
penemuan manusia yang
paling menakjubkan: manusia
sungguh-sungguh "sapiens"
(bijaksana, berbudi) hanya
karena ia "loquens"
(bertutur), yaitu karena ia
dapat belajar bercakap. Sejak


manusia pertama (primitif) tidak ada perubahan dalam tubuh, namun psikisnya tidak sama seperti dulu: manusia telah mengembangkan kecerdasan budinya berkat bahasa dan kemajuankemajuan yang dicapainya. Binatang tanpa bahasa, maka tetap, tidak ada kemajuan (Chauchard 1983:13)

Dikarenakan terkait dengan hakikat manusia, pemerolehan bahasa menjadi bahasan yang menarik untuk dikembangkan, utamanya pemerolehan bahasa anak usia dini. Kecerdasan kinestetik sekali lagi dapat disandingkan dengan kecerdasan bahasa anak, prinsip anak yang suka bergerak dapat dimanfaatkan pada kemampuan verbal dengan membaca dan menebak makna atau nama dari sebuah gerakan yang ditimbulkan oleh respek atau manipulasi gerak anak.

Banyak teori tentang pemerolehan bahasa seperti yang di kemukakan oleh Saryono (2010), ada empat teori pemerolehan bahasa yang sangat populer yaitu: (1) Teori pengondisian Opera Skinner yang berumpun behavioristis, (2) Teori Nativis LAD Chomsky yang berumpun nativis, (3) Teori Konstruksi Kreatif Dulay dan Burt, dan (4) Teori Monitor Krashen yang berumpun konstruktivistis.

\footnotetext{
Salah satu teori tersebut menjelaskan bahwa manusia memperoleh bahasa dari lingkungan sekitar, Teori pengondisian Opera Skinner behavioris mengutamakan perilaku nyata yang dapat diindra dan dapat diukur secara pasti, perilaku nyata itu berupa perilaku
}

78 | Jurnal Kredo Vol. 1 No. 1 Oktober 2017 verbal. Disamping itu, psikologi behavioris memperhatikan fokus pada perananan faktor-faktor eksternal bukan internal dalam diri manusia. Dalam pemerolehan prilaku verbal (bahasa) perlu juga rangsangan perilaku gerak tubuh untuk menunjang literasi pada diri seseorang utamanya anak usia dini.

\section{Kompetensi Berbahasa}

Beberapa ahli berpendapat
bahwa kemampuan berbahasa seseorang terdapat pada diri orang itu yang didapat secara alami dan bersifat kodrat (narture), namun ahli yang lain berpendapat bahwa kemampuan berbahasa didpat bukanlah kondratiah, kompetensi berbahasa adalah nurture, yaitu kompetensi yang diperoleh melalui pendidikan dan kultural.

Menurut Dardjowidjojo (dalam Baryadi, dkk. 2004:14) baik narture maupun nurture diperlukan untuk pengembangan bahasa. Narture diperlukan karena tanpa bekal kodrat kompetensi berbahasa, kompetensi berbahasa seseorang tidak mungkin bisa dikembangkan. Sedangkat nurture diperlukan karena tanpa adanya dukungan dari lingkungan (misal pendidikan), kompetensi berbahasa yang bersifat kodrat itu tidak akan berkembang.

Dalam pendidikan berbahasa, penekanan pada perkembangan kompetensi berbahasa peserta didik perlu diperhatikan. Hal ini sangat penting untuk menjaga kesinambungan perkembangan kompetensi bahasa yang mereka peroleh untuk mendapatkan bahasa yang lebih tinggi.

Untuk itu perlu ulasan dan pencerahan dari beberapa ahli bahasa 
kaidah dan fakta sosial yang berifat kolektif

$$
\text { Parole merupakan }
$$

bahasa sebagai ujaran yang bersifat individual, bahasa yang bersifat heterogen, serta sesaat. Sedangkan langage merupakan bentukan kesepakatan para individu yang memiliki parole. Sebaliknya, parole yang dimiliki oleh para individu merupakan manifestasi kaidah-kaidah hasil kesepakatan bersama.

Dapat diartikan bahwa langage ialah gabungan kaidah bahasa dan penggunaannya bersifat individual. Artinya, langage menunjuk gabungan langue dan parole

\section{e. Pandangan \\ Chauchard}

Paul

Paul Chauchard menyatakan bahwa manusia dan binatang memiliki persamaan yakni sama-sama memiliki pemikiran, yang membedakan keduanya adalah kata-kata dalam mengungkapkan isi pikirannya, sedangkan binatang tidak memiliki hal tersebut.

Lebih jauh Paul Chauchard mengungkapkan bahwa pikiran tidak dapat dipergunakan tanpa bahasa, keduanya bersifat stimultan. Bahasa merupakan sarana berfikir dan sarana untuk mengungkapkannya. Berkenaan dengan hal itu, bahasa dibagi menjadi dua, "bahasa ke dalam" dan "bahasa ke luar".

dipakai "Bahasa ke dalam" imajinasi, refleksi, merenungkan

80 | Jurnal Kredo Vol. 1 No. 1 Oktober 2017 sesuatu, atau menimbangnimbang. Sedangkan"bahasa ke luar" dipergunakan untuk mengungkapkan isi pikiran tersebut ke dalam bahasa yang bisa dipahami oleh orang lain.

\section{f. Pandangan Howard Gardner}

Gardner mengungkapkan bahwa kecerdasan bahasa setiap anak dilahirkan dengan kemampuan berbahasa yang berbeda, ada anak yang memiliki kecerdasan bahasa yang menonjol dari pada yang lain.

Kompetensi berbahasa
menurut Gardner merupakan
kompetensi bawaan, karena
bersifat bawaan seperti halnya
benih yang bisa tumbuh dan
berkembang. Perkembangan
tersebut dapat berkembang secara
positif atau sebaliknya. Untuk itu
kompetensi berbahasa menurut
Gardner yang terdapat pada anak
perlu dikembangkan meskipun
merupakan kompetensi bawaan.

Dari uraian di atas yang telah penulis rangkum dari Baryadi, dkk. (2004) menunjukkan bahwa kompetensi manusia perlu dikembangkan, bahasa merupakan pembeda manusia dengan makhluk lainnya. Keterampilan berbahasa merupakan alat komunikasi interaktif terhadap yang lainnya, kompetensi berbahasa mencakup keterampilan pengetahuan berbahasa dan bahasa itu sendiri, serta kaidah-kaidah sosial dalam strategi berkomuniksi.

\section{B. Kepaduan Literasi bahasa}


Kita mungkin sejenak akan berfikir, bagaimana kecerdasar kinestetik yang memang condong pada gerakan fisik mampu dipadukan dengan kebiasaan membaca dan menulis yang cenderung pada olah otak? Oleh karena itu dalam tulisan ini mencoba dengan bahasa sederhana menemukan jawaban tersebut.

Dalam pembelajaran diperlukannya sebuah strategi untuk mencapai tujuan yang diinginkan, juga di dalamnya dalam pembelajaran bahasa. Menurut Oxford (1990) diperlukan strategi metakognitif dalam strategi belajar bahasa, strategi metakognitif memberikan dukungan pada pembelajaran bahasa dalam hal focusing, planning dan evaluating.

Strategi pembelajaran bahasa tersebut dapat diadopsi dalam pemanfaatan kecerdasan kinestetik untuk memperoleh budaya litersi bahasa, sebab demikian budaya literasi bahasa juga dipengaruhi oleh strategi belajar bahasa seseorang.

Focusing sangat penting dalam belajar, untuk mendorong literasi bahasa dengan memanfaatkan kecerdasan kinestetik diperlukan dorongan agar mampu memunculkan gerakan-gerakan yang memiliki arti atau sebuah tebakan yang mengandung jawaban pada pembelajaran bahasa. Peserta didik tidak hanya dituntut untuk aktif bergerak melainkan harus memberikan kontribusi memainkan peran dan menciptakan gerakangerakan baru untuk memunculkan kosa kata, kalimat, atau frasa baru yang memancing rasa ingin tahu.
Planning ditujukan agar guru, orang tua, atau anak mampu membuat rencana untuk menciptakan hal-hal unik lainnya untuk dikembangkan dan dibudayakan dalam pembelajaran bahasa. Artinya tidak hanya bergantung pada apa yang sudah ada akan tetapi menciptakan, merencanakan, mengaplikasikan, dan mengembangkan kemampuan berbahasa dengan menciptakan gerakan-gerakan baru pada kosa kata, kalimat, atau frasa baru pula.

Evaluating dibutuhkan untuk mengukur sejauh mana efektifitas hasil dari proses penciptaan gerakangerakan baru terhadap budaya literasi bahasa, apakah pemanfaatan kecerdasan kinestetik berdampak positif terhadap budaya literasi pada umumnya atau literasi bahasa khususnya.

\section{1) Budaya literasi di rumah}

Aktifitas literasi

diharapkan tumbuh mulai dari lingkungan terdekat yaitu keluarga, Tinjauan sosial-kultural menjelaskan perolehan kemampuan bahasa dan literasi anak prasekolah terjadi dalam konteks kehidupan sehari-hari yang bermakna melalui keterlibatan aktif dalam aktivitas yang nyata dalam lingkungan mikrosistem yaitu keluarga (Ruhaena: 2015).

(2015) mengungkapkan bahwa Aktivitas ini diarahkan oleh orang dewasa di rumah terutama orang tua sehingga tercipta interaksi sosial yang merangsang potensi kognitif, bahasa, dan literasi anak prasekolah. 
Orang tua sebagai garda terdepan yang sering berinteraksi dengan anak dapat memanfaatkan masa emas mereka untuk menumbuhkan dan membudayakan literasi yang dimulai dari rumah, sehingga perkembangan anak terutama pemerolehan bahasa dapat terjadi secara berkesinambungan.

\section{2) Budaya Literasi di Sekolah}

Budaya literasi di sekolah sangat penting untuk diberdayakan, budaya literasi bisa dimasukkan dalam strategistrategi pembelajaran di setiap mata pelajaran. Strategi tersebut seperti Two Stay Two Stay, Jigsaw, menulis berputar (Write Around), model pembelajaran TPS (Think Pairs Share). TAI (Team Assisted Individualization), STAD (Student Teams Achievment Division), dan STL (Student TeamLearning).

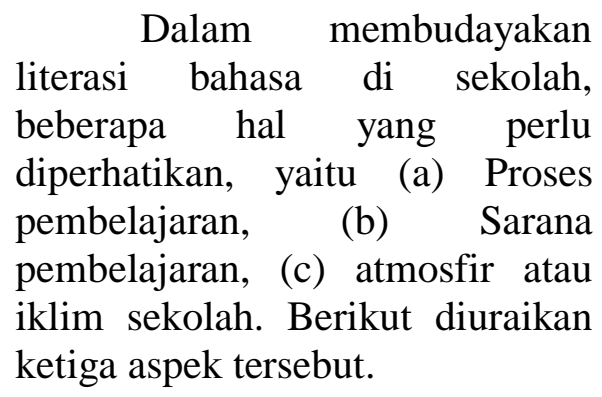

\section{a. Proses Pembelajaran}

Dalam proses belajarmengajar (pembelajaran) pada pembelajaran bahasa, merupakan "ruh" dari budaya literasi bahasa itu sendiri. Perlu berapa teknik dan strategi yang harus dilakukan oleh guru dan peserta didik seperti strategi belajar yang diuraikan di atas, dengan pengunaan strategi yang tepat maka tujuan dari budaya literasi di sekolah akan mudah tercapai.

Pada proses pembelajaran selain strategi juga diperlukan bahan ajar, model pembelajaran, dan penilaian terhadap hasil yang telah dicapai.

\section{b. Sarana Pembelajaran}

Sarana pembelajaran mempunyai peran penting, misalkan seperti penyediaan buku dan media pembelajaran.

Membudayakan literasi bahasa di lingkungan sekolah akan lebih mudah dilaksanakan apabila sarana seperti penyediaan buku mendukung, masyarakat sekolah akan lebih mudah menjangkau sarana yang didapatkan untuk mengembangkan kemampuan berbahasa dan pembiasaan literasi.

\section{c. Atmosfer atau Iklim Sekolah}

Lingkungan menjadi hal yang penting selain dari pada sarana pembelajaran, lingkungan yang baik akan membantu perkembangan yang positif bagi anak. Atmosfer yang diciptakan oleh pihak sekolah dan guru mempengaruhi pada sikap dan prilaku anak, tidak dapat dipungkiri pula akan budaya literasi.

Pada tatanan sekolah dasar, iklim literasi utamanya literasi bahasa merupakan 


\begin{abstract}
kegiatan yang perlu diciptakan. Seperti yang jamak terjadi dengan memberikan himbauan atau gambar-gambar dan teks pesan-pesan moral yang ditampilkan di lingkungan sekolah, namun yang demikian yang sering dijumpai pesan-pesan tersebut dikemas dengan kurang menarik bahkan tidak ada upaya memperbaharui dari segi penampilan, sehingga akan berfungsi sesaat dan lama kelamaan dianggap barang "basi". Di sini artinya pembelajaran literasi hanya berjalan sesaat tanpa berkesinambungan.
\end{abstract}

\section{Pembelajaran Literasi Bahasa Melalui Kecerdasan Kinestetik}

Dalam sebuah pembelajaran, terutama dalam pembelajaran bahasa yang jamak dijumpai adalah mengajak peserta didik untuk mengolah daya ingat mereka yaitu dengan hafalan. Baik yang bersifat memaksa, setengah memaksa atau hanya sekedar menyarankan.

Dalam budaya literasi
memang memerlukan sedikit
paksaan agar budaya tersebut dapat
berjalan dengan yang diharapkan,
namun apabila hal demikian terus
menerus dilakukan tidak menutup
kemungkinan peserta didik akan
merasa jenuh dan "ogah"
melaksanakan kegiatan literasi.
Untuk itu diperlukan pemanfaatan
kecerdasan yang lain untuk
merangsang budaya literasi tersebut,
salah satunya melalui kecerdasan
kinestetik.

Berikut beberapa contoh gerakan yang dapat dipakai untuk mencapai budaya literasi pada anak usia dini dan tingkat sekolah dasar.

\section{a. Belajar kosa kata baru}

Langkah ini adalah jalan dasar anak mempelajari bahasa baru setelah bahasa ibu, atau pun setelah bahasa Indonesia terhadap bahasa asing seperti bahasa Inggris. Anak di sekolah akan mempelajari kosa kata baru dalam bahasa Indonesia karena bahasa yang dipakai dalam sehari-hari adalah bahasa daerah atau belajar bahasa Indonesia baku bagi anak yang menggunakan bahasa Indonesia tidak baku seperti orang betawi yang menggunakan kata "ello/ente" yang berarti "kamu".

Erat kaitannya dengan literasi, anak yang masih senang melakukan aktifitas fisik bisa dialihkan membaca atau menuliskan dari sebuah gerakan. Mari ambil kosa kata dari kata benda profesi "petani". Guru menuliskan kata "Petani" di papan tulis kemudian meminta anak untuk menirukan sebuah gerakan. Berikut tahapannya:
1. Kata "petani" dapat diwakilkan dengan gerakan memegang cangkul lalu seolah mencangkul seraya mengucapkan "petani”.

2. Ulangi gerakan memegang cangkul lalu 


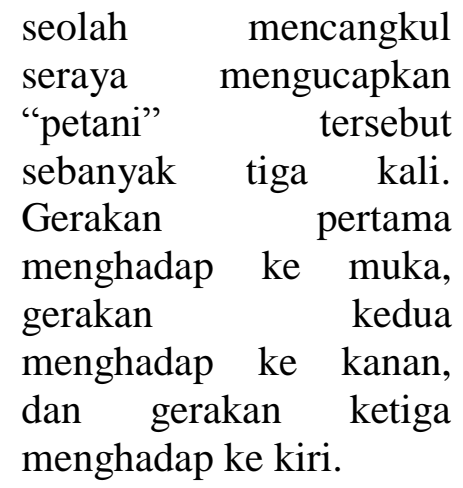

3. Mintalah anak membaca tulisan "petani" di papan kemudian melakukan gerakan seperti poin nomer 1 dan lakukan berulang sebanyak tiga kali seperti poin nomer 2 .

\section{Lakukan}

pembelajaran kosa kata baru ini dengan variasi-variasi kreatif guru dan anak, setiap kosa kata dapat dicari gerakan yang sesuai dengan karakter, ciri, atau mewakili dari kosa kata tersebut. Misal kata "pintu" dengan gerakan membuka dan menutup sesuatu, "kucing" dengan tangan mencakar dan menirukan bunyi "meong", dan lain sebagainya.

Dalam pembelajaran kosa kata baru semacam demikian haruslah ditekankan anak membaca terlebih dahulu dari sebuah tulisan tangan guru di papan atau tulisan cetak yang ditempel di dinding kemudian meminta anak melakukan gerakan yang sesuai, jangan sampai terjebak dengan permainan gerakan semata dengan hanya menyebutkan sebuah kosa kata tanpa menuliskannya. Jika itu terjadi maka tujuan penanaman literasi sejak dini akan sulit tercapai.

\section{b. Belajar Frasa dan kata majemuk baru}

Frasa yang berarti gabungan dua kata atau lebih yang mempertahankan makna dasarnya, seperti "lapangan luas" yang berarti lapangan yang berukuran luas, atau "langit tinggi" yang bermakna langit yang berada tinggi di atas. Sedangkan kata majemuk adalah gabungan antara dua kata atau lebih yang membentuk makna baru, seperti "rumah sakit" berarti tempat orang berobat untuk sembuh dari suatu penyakit/sakit bukan rumah yang sakit.

belajar frasa atau kata majemuk baru tidak jauh berbeda dengan pembelajaran kosa kata baru, hanya saja di sini akan muncul kosa kata baru yang terdiri lebih dari satu kata.

Dalam pembelajaran frasa dan kata majemuk baru dengan pemanfaatan kecerdasan kinestetik anak memang lebih terbatas dari pada belajar kosa kata, dengan demikian melatih anak dalam belajar frasa dan kata majemuk baru harus betul-betul cermat memilih frasa dan kata majemuk yang akan dimunculkan. Sebagai contoh kita dapat mengambil frasa "jalan santai", guru dapat memberi contoh gerakan jalan perlahan sambil mengucapkan "jalan santai" 
sebanyak tiga kali masingmasing pertama menghadap ke muka, kedua belok ke kanan, dan ketiga belok ke kiri.

Frasa "lari cepat" juga bisa dimanfaatkan bagi anak untuk mengetahui perbedaan antara "lari" dan "jalan", juga "santai" dan "cepat". Guru dapat menuliskan keduanya sekaligus "jalan santai" dan "lari cepat"

Setelah diberi contoh gerakan yang sesuai frasa yang anak baca di papan tulis, langkah berikutnya guru dapat memanfaatkan lebih spesifik lagi akan kecerdasan kinestetik anak. Mintalah anak untuk menuliskan frasafrasa dan kata-kata majemuk baru dan harus membuat dan menciptakan gerakan baru yang sesuai dengan apa yang mereka tulis. Kemudian guru bisa meminta anak membacakan tulisannya dan mempraktikkan gerakan kreasinya, atau guru dapat menyuruh temannya membacakan tulisan si anak kemudian yang anak tersebut melakukan gerakan yang sesuai dengan apa yang dbacakan oleh temannya tersebut. Langkah pemberian tugas untuk menuliskan frasa baru ini juga dapat dipraktikkan dalam pembelajaran kosa kata baru.

\section{c. Pembelajaran kalimat}

kalimat pembelajaran diterima oleh guru lebih berat lagi. Guru harus lebih kreatif sebelum meminta anak didiknya mengkreasikan sebuah kalimat dalam sebuah gerakan.

Umumnya ketika seseorang membaca kalimat sambil melakukan gerakan adalah saat berdongeng, kemampuan kinestetik anak dapat dimanfaatkan untuk melatih membaca kalimat memang lebih mudah dengan kalimat cerita atau dongeng. Sekali lagi, di sini yang ditekankan adalah menumbuhkan literasi anak, yaitu bagaimana ketika anak suka dongeng bukan merengek meminta dibacakan dongeng melainkan berhasrat untuk membaca sendiri cerita yang mereka inginkan.

\section{Menumbuhkan}

budaya literasi dengan pemanfaatan kecerdasan kinestetik anak dalam pembelajaran kalimat dapat dimulai dengan kalimat sederhana yang ringan, mintalah mereka mencari buku cerita di perpustakaan adalah solusi bagi guru yang kewalahan untuk menuliskan kalimat panjang berkali-kali di papan tulis. Namun demikian langkah pertama memang harus dimulai dari kalimat yang ditulis oleh guru di papan tulis sebagai contoh pembelajaran permulaan.

Contoh guru menuliskan kalimat:

"seekor burung kutilang terbang mengitari pepohonan, 
lalu hinggap di ranting pohon dan berkicau dengan indahnya"

Guru bisa memberikan contoh gerakan tangan mengepak seperti burung yang terbang, kemudian tangan kanan melakukan gerakan seperti meyerong pada saat membaca kalimat "lalu hinggap di tanting pohon", kemudian bersiul setelah membacakan kalimat "berkicau dengan indahnya".

Mintalah anak untuk membaca kalimat tersebut dan melakukan gerakan seperti apa yang dilakukan oleh gurunya, yang perlu diperhatikan adalah apabila ada anak yang membuat gerakan lain atau berbeda dengan contoh gerakan gurunya itu merupakan sebuah kreatifitas anak yang perlu didukung.

\section{d. Pembelajaran Bahasa kedua (bahasa asing)}

Dari seluruh poin a-c dijabarkan dengan contoh kemampuan pemerolehan bahasa pertama (bahasa Indonesia), uraian di atas memberikan contoh pemerolehan bahasa Indonesia untuk lebih dipahami. Untuk pengembangan pada kecakapan berbahasa asing seperti bahasa Inggris, bahasa Arab, dan bahasa asing lainnya, metode pemanfataan tersebut juga mampu diterapkan.

86 | Jurnal Kredo Vol. 1 No. 1 Oktober 2017
Mari kita ambil contoh pembelajaran kosa kata baru bahasa Inggris, taruhlah kata "farmer", gerakan yang bisa dipakai bisa menggunakan gerakan yang sama pada kata "petani" yaitu seolah-olah memegang jangkul kemudian mencangkul sambil mengucapkan "farmer" dan dilakukan berulang sebanyak tiga kali dari arah muka, kemudian ke arah kanan, dan terakhir ke arah kiri.

Praktik ini juga merangsang anak untuk mencari kosa kata bahasa Inggris baru untuk mencari gerakan baru, artinya anak terpacu membaca untuk mendapatkan kosa kata baru untuk menciptakan gerakan baru. Sebaliknya, ketika anak mempunyai gerakan baru untuk gerakan yang ia miliki namun hanya mengetahui makna kata dalam bahasa Indonesia saja akan tetapi belum mengetahui kosa kata tersebut dalam bahasa Inggris, maka memancing anak untuk mencari tahu bahasa Inggrisnya, nah, disinilah guru dapat mengajak anak untuk mencari tahu dengan membaca kamus atau buku-buku saku bahasa Inggris. Dalam pemerolehan bahasa asing lain, tentu dapat menyesuaikan kosa kata apa yang akan diberikan kepada anak.

Pada pembelajaran frasa, kata majemuk, dan kalimat dalam pemanfatan kecerdasan anak untuk 
perolehan bahasa asing masih sangat berat. Kalau hanya sekedar kompetensi komunikatif semata mungkin masih bisa, namun jika lebih pada kompetensi komunikatif sempurna akan terasa sangat sukar karena terkendala dengan pola gramatikal bahasa asing yang berbeda dengan bahasa Indonesia. Mengingat kesukaran itu, guru juga diharapkan untuk mencobanya dalam frasa, kata majemuk, dan kalimat untuk pemanfaatan kecerdasan kinestetik untuk perolehan bahasa asing, karena dengan mencoba masih ada kemungkinan untuk berhasil.

Berikut tabel contoh kosa kata bahasa Inggris dan gerakan yang dibutuhkan untuk pengembangan kemampuan bahasa dan pembudayaan literasi bahasa.

Tabel 1. Contoh penggunaan kinestetik dalam bahasa Inggris

\begin{tabular}{|c|c|c|}
\hline No & Kosa Kata & Gerakan \\
\hline 1. & Soldier & $\begin{array}{l}\text { Kedua tangan mengarah ke depan dan posisi seperti } \\
\text { memegang senjata, kemudian acungkan ke depan sambil } \\
\text { berteriak "soldier", menghadap ke kiri berteriak } \\
\text { "soldier", lalu menghadap ke kanan berteriak lagi } \\
\text { "soldier" }\end{array}$ \\
\hline 2. & Police & $\begin{array}{l}\text { Tangan kiri seolah memegang pluit di depan mulut, } \\
\text { tangan kanan seperti mengatur lalu lintas lalu berteriak } \\
\text { "police", ulangi sebanyak 3x. }\end{array}$ \\
\hline 3. & Teacher & $\begin{array}{l}\text { Gerakan pertama seolah menulis dan berteriak } \\
\text { "teacher", gerakan kedua seolah membuka buku dan } \\
\text { berteriak "teacher", gerakan ketiga kembali seperti } \\
\text { gerakan pertama seolah menulis dan berteriak "teacher" }\end{array}$ \\
\hline 4. & Table & $\begin{array}{l}\text { Kedua tangan arahkan ke depan, kedua jari telunjuk di } \\
\text { satukan, kemudian buka kekanan dan ke kiri berteriak } \\
\text { "ta" dan ditarik ke belakang "ble". Kedua jari maju } \\
\text { berteriak "ta", kemudian kedua jari telunjuk merapat } \\
\text { sambil berteriak "ble" }\end{array}$ \\
\hline 5. & Door & $\begin{array}{l}\text { Tangan seolah membuka pintu di depan dan berteriak } \\
\text { "door", seolah membuka pintu di samping kiri sambil } \\
\text { berteriak "door", dan seolah membuka pintu di samping } \\
\text { kakan dan berteriak "door" }\end{array}$ \\
\hline 6. & Cat & $\begin{array}{l}\text { Kedua tangan seolah mencengkram lalu berteriak } \\
\text { "meong", ulangi sebanyak } 3 \mathrm{x}\end{array}$ \\
\hline 7. & Cow & $\begin{array}{l}\text { Kedua telapak tangan terbuka di depan mulut seperti } \\
\text { memanggil orang di kejauhan, kemudian berteriak } \\
\text { "cow", menghadap ke kiri berteriak lagi "cow", } \\
\text { menghadap ke kanan berteriak "cow" lalu menghadap } \\
\text { ke depan dan berteriak "mmmmoooooohh" }\end{array}$ \\
\hline 8. & Delicious & $\begin{array}{l}\text { Tangan mengusap mulut dan berteriak "mmmm } \\
\text { delicious". Ulangi sebanyak } 3 \mathrm{x}\end{array}$ \\
\hline
\end{tabular}




\section{Contoh-contoh}

tersebut bukanlah gerakan yang baku pada satu kata atau sebaliknya, lebih disarankan mengembangkan dan menciptakan gerakan-gerakan baru pada kosa kata tersebut dan kosa kata yang lainnya.

\section{Contoh Pembelajaran Literasi Bahasa di Kelas}

Dalam tahap pembelajaran di kelas, dikenal tiga tahap yaitu (1) perencanaan, (2) pelaksanaan, dan (3) refleksi. Pada kajian berikut akan diberikan contoh pembelajaran literasi bahasa asing (Inggris) memanfaatkan kecerdasan kinestetik.

a. Tahap Perencanaan

Yang dilakukan guru pada tahap ini adalah:

1) Menentukan kompetensi dasar

2) Menentukan materi pokok yang tersirat dalam $\mathrm{KD}$

3) Merumuskan sejumlah indikator

4) Berdasarkan materi pokok dan sejumlah indikator, guru mengembangkannya menjadi bahan ajar lengkap yang diperoleh dari berbagai sumber yang relevan

5) Menyiapkan media dan alat pembelajaran yang dianggap sesuai
6) Menyiapkan lembar kerja siswa (LKS) sebagai alat ukur kemampuan siswa

7) Menyusun alat evaluasi pembelajaran yang sesuai dengan materi

8) Menyusun kegiatan berupa rencana pelaksanaan pembelajaran (RPP)

b. Tahap Pelaksanaan

Pada tahap pelaksanaan di sini, guru melaksanakan pembelajaran sesuai dengan rencana pelaksanaan pembelajaran (RPP) yang telah disusun sebelumnya menggunakan referensi dan media yang sudah disiapkan. Dalam pelaksanaan pembelajaran, guru melakukan kegiatan yang terbagi atas tiga tahap, yaitu kegiatan awal, kegiatan inti, dan kegiatan penutup. Berikut diuraikan contoh ketiga tahap kegiatan pembelajaran tersebut.

1) Kegiatan Awal

- Guru memberi kosa kata (misal Cow) sambil memperagakan sesuatu tersebut (bisa melihat contoh di tabel.1) yang bisa memberikan gambaran akan benda (kosa kata) yang diucapkan

- Siswa menebak arti kosa kata tersebut

- Guru memberi penguatan jawaban siswa

2) Kegiatan Inti 
- Guru memberi beberapa contoh kosa kata baru dan memperagakan gerakan-gerakan yang "mewakili" arti kosa kata tersebut

- Siswa menebak arti kosa kata tersebut

- Guru meminta siswa mencari kosa kata baru dan gerakangerakan yang "mewakili" kosa kata tersebut

- Guru meminta siswa memperagakan di depan kelas dan memperagakan gerakangerakan yang "mewakili" kosa kata yang dibuat untuk ditebak oleh teman sejawatnya

- Guru memberi penguatan hasil kerja siswa

\section{3) Kegiatan Penutup}

- Guru menyimpulkan pelajaran

- Guru memberi tugas gerakangerakan beberapa kosa kata baru yang diberikan oleh guru

\section{c. Tahap Refleksi}

Pada tahap refleksi guru dan siswa dapat mengealuasi hasil kegiatan pembelajaran, tahap refleksi dilaksanakan pada akhir pelajaran. Guru dan siswa bisa membuat catatan evaluasi untuk membuat perbaikan atas kekurangan yang dilakukan pada proses pembelajaran untuk ditidaklanjuti pada pertemuan berikutnya.

\section{SIMPULAN}

Selain bertumpu pada kecerdasan kinestetik anak, membudayakan literasi bahasa juga membutuhkan dorongan yang kuat dari orang sekitarnya, guru atau orang tua anak. Pun demikian kemampuan kinestetik anak sejatinya sudah cukup modal untuk membudayakan literasi bahasa, karena anak kerap kali memaknai sebuah bahasa dengan jawaban pola gerak.

Peran guru dalam pemberdayaan kecerdasan kinestetik bertumpu pada penataan dan arahan, dalam perspektif literasi bahasa, guru menjadi pelatih anak dalam pemerolehan bahasa yang baik yang komunikatif serta kritis. Ketika anak sudah mampu memaknai dari setiap gerakan yang mereka ciptakan, guru bisa hadir memberi tantangan serta mengasah kemampuan berbahasa anak, kesempatan berbahasa anak diarahkan pada kreatifitas kritis yang dituangkan dalam ide imajinatif dan menuliskan banyak kata, frasa, kata majemuk, dan kalimat baru dalam catatan harian mereka, juga terdorong untuk mencari referensireferensi baru dalam berbahasa untuk mengkreasikan atau sekedar mencocokkan dengan gerakangerakan baru yang mereka peroleh. Maka diharapkan anak mampu mengembangkan kecerdasan kinesteniknya dan menular dalam kecerdasan literasi pada umumnya serta literasi bahasa pada khususnya. 


\section{DAFTAR PUSTAKA}

Baryadi, I.Praptomo, dkk. (2004). Bahasa Merajut Sastra Merunut Budaya.Yogyakarta: Penerbitan Universitas Sanata Dharma Yogyakarta

Buckingham, D. (2007). Digital Media Literacies: rethinking media education in the age of the Internet. Research in Comparative and International Education, 2(1), 43-55.

Chauchard, Paul.(1983). Bahasa dan Pikiran. Diterjemahkan oleh Widyamartaya. Yogyakarta: penerbit kanisius

Haryanti, Trini. (2014). membangun karakter-bangsa-melalui-literasi-digit. (www.pustakaindonesia.org) diakses tanggal 28 agustus 2016

Musfiroh, Tadkiroatun. (2008). Cerdas Melalui Bermain, Jakarta: PT Grasindo

Ruhaena, Lisnawati (2015). Model Multisensori: Solusi Stimulasi Literasi Anak

Prasekolah. Jurnal Psikologi Volume 42, NO. 1, APRIL 2015: 47 - 60

Saryono, Djoko. (2010). Pemerolehan Bahasa: Teori dan Serpih Kajian. Malang: Nasa Media

Subandiyah, Heni (2015). Pembelajaran Literasi dalam Pelajaran Bahasa Indonesia.http://ejournal.unesa.ac.id/article/714/32/article.pdf. diakses tanggal 28 Agustus 2016

Supriyadi, D. (2001). Kreativitas Kebudayaan \& Perkembangan Iptek, Bandung: Alfabeta

90 | Jurnal Kredo Vol. 1 No. 1 Oktober 2017 